\title{
TINGKAT PENCEMARAN PERAIRAN DANAU LIMBOTO GORONTALO
}

\author{
(Water Pollution Level Of Limboto Lake Of Gorontalo)
}

\author{
Sri Yuningsih Noor $^{1^{*}}$ dan Meriyanti Ngabito² \\ 1,2Program Studi Perikanan dan Ilmu Kelautan, Universitas Gorontalo. \\ Email : yuyun.noor@gmail.com
}

\begin{abstract}
Abstrak
Danau Limboto kini berada pada kondisi yang sangat memperihatinkan karena mengalami proses penyusutan dan pendangkalan akibat sedimentasi dan tempat pembuangan sampah yang mengancam keberadaan ekosistem dimasa yang akan datang. Berdasarkan permasalahan tersebut, maka dilakukanlah penelitian dengan judul tingkat pencemaran Perairan Danau Limboto Gorontalo. Pengukuran beberapa parameter kualitas air dilakukan secara insitu pada 8 (delapan) stasiun yang dilakukan secara sampling dan analisis laboratorium beberapa parameter kualitas air dilakukan pada Balai Riset dan Standardisasi Industri Manado. Tingkat pencemaran pada perairan Danau Limboto dihitung menggunakan indeks pencemaran Kirchoff 1991 dan indeks pencemaran logam berat menurut KepmenLH No. 115 Tahun 2003. Hasil Penelitian menunjukkan bahwa tingkat pencemaran stasiun 1, 2, 3, 4 dan 5 tergolong tercemar ringan dengan nilai indeks kimia kirchoff berkisar 59.13-70.64, sedangkan stasiun 6,7 dan 8 tergolong tercemar sedang dengan nilai indeks kimia kirchoff berkisar 42.58-55.82. Tingkat pencemaran logamberat $\mathrm{Pb}$ dan $\mathrm{Cd}$ pada perairan Danau Limboto masih berada dalam kondisi normal dengan nilai indeks pencemaran logam $0 \leq$ PIj $\leq 1$ yaitu memenuhi baku mutu (kondisi baik).
\end{abstract}

Kata Kunci : Tingkat Pencemaran, Danau Limboto, Indeks Kirchoff

\section{Abstract}

Lake of Limboto were on the worried condition now. It happened because of the process depreciation and sedimentation which caused by sedimentation and waste ground that threaten the existence of ecosystem in the future. Based on these problems, so did research with a title water pollution level of Limboto Lake of Gorontalo. The measurement of the quality of water carried out some parameters in 8 (eight) station, it will be done in the sampling method of and analysis laboratory some parameters the quality of water is carried on Manado Research and Standardization Reasearch Centre. To determine the water pollution level of Limboto Lake calculated use of pollution index of Kirchoff (1991) and heavy metal pollution index of KepmenLh No. 115 (2003). The results of the study showing that the water pollution level at station 1, 2, 3, 4, and 5 classified as lightly contaminated areas with index Kirchoff value range of 59.13-70.64, while at station 6,7 , and 8 including being moderatly contaminatedwith index Kirchoff value range of 42.58-55.82. The heavy metal pollution level of $\mathrm{Pb}$ and $\mathrm{Cd}$ classified in normal condition with the pollution index range $0 \leq P I j \leq 1$.

Keyword: Level of Pollution, Limboto Lake, Index Kirchoff. 


\section{PENDAHULUAN}

Danau Limboto merupakan sumberdaya alam yang dimiliki Provinsi Gorontalo saat ini. Danau Limboto telah berperan sebagai sumber pendapatan bagi nelayan, pencegah banjir, sumber air pengairan dan obyek wisata. Areal danau ini berada pada dua wilayah yaitu $+30 \%$ wilayah Kota Gorontalo dan $+70 \%$ di wilayah Kabupaten Gorontalo dan menjangkau 5 kecamatan. Danau Limboto kini berada pada kondisi yang sangat memperihatinkan karena mengalami proses penyusutan dan pendangkalan akibat sedimentasi dan pembuangan sampah yang mengancam keberadaanekosistem dimasa yang akan datang. Semakin berkurangnya luasan perairan danau menyebabkan semakin menurunnya fungsi danau sebagai kawasan penampung air dan tempat hidup biota perairan sehingga berpotensi terjadinya banjir dan hilangnya organisme endemik yang ada di Danau Limboto (Pemerintah Provinsi Gorontalo, 2016)

Kondisi yang terjadi pada saat ini tidak terlepas dari aktivitas masyarakat sekitar yang berkaitan dengan kegiatan perladangan berpindah yang telah berlangsung lama. Akibatnya terjadi kerusakan lingkungan yang ditandai adanya erosi, banjir pada musim hujan, dan kekeringan pada musim kemarau di wilayah Gorontalo dalam 2 tahun terakhir. Dampak langsung yang terjadi pada perairan Danau Limboto saat ini sudah terlihat seperti pendangkalan dan eutrofikasi sebagai akibat meningkatnya nutrien dan zat pencemar ke badan perairan danau. Cepatnya proses penyuburan dan sedimentasi di Danau Limboto mengakibatkan fungsí utama dari danau berkurang, seperti sebagai peredam banjir pada musim hujan dan penyedia air pada musim kemarau, serta sebagai habitat beberapa jenis ikan. Berdasarkan permasalahan tersebut, maka dilakukanlah penelitian dengan judul tingkat pencemaran Perairan Danau Limboto Gorontalo.

\section{METODE PENEITIAN}

\section{Waktu dan Tempat}

Pengambilan sampel penelitian dilakukan pada 8 (delapan) stasiun di perairan Danau Limboto Pengukuran beberapa parameter kualitas air dilakukan secara insitu dan pengujian parameter kualitas air lainnya dilakukan di laboratorium Balai Riset dan Standardisasi Industri Manado. Peta lokasi penelitian dapat dilihat pada Gambar 1. 


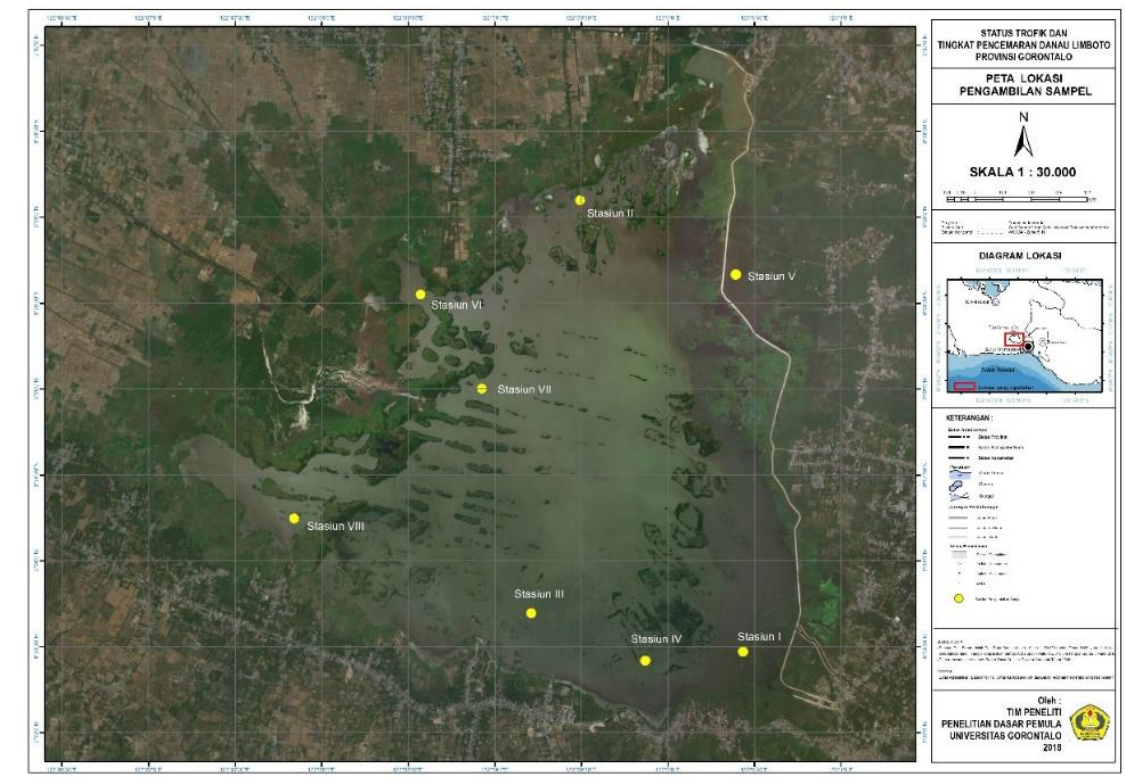

Gambar 1. Peta Lokasi Penelitian

Tabel 1. Stasiun Penganbilan sampel di Danau Limboto

\begin{tabular}{cccc}
\hline Station & Location & Position & Keterangan \\
\hline \multirow{2}{*}{1} & Kelurahan & $0.591497^{\circ} \mathrm{LU}$ & Outlet Danau \\
& Tabumela & $122.996552^{\circ} \mathrm{BT}$ & Limboto \\
& Kelurahan & $0.590522^{\circ} \mathrm{LU}$ & Daerah \\
& Hutuo & $122.980772^{\circ} \mathrm{BT}$ & Pertanian \\
& Kelurahan & $0.581304^{\circ} \mathrm{LU}$ & Area Keramba \\
3 & Dembe & $122.991008^{\circ} \mathrm{BT}$ & Jaring Apung \\
& Kelurahan & $0.576612^{\circ} \mathrm{LU}$ & \\
4 & Lekobalo & $123.003564^{\circ} \mathrm{BT}$ & Pemukiman \\
& Kelurahan & $0.562595^{\circ} \mathrm{LU}$ & Area Eceng \\
5 & Lupoyo & $123.005090^{\circ} \mathrm{BT}$ & Gondok \\
\multirow{5}{*}{6} & Kelurahan & $0.560342^{\circ} \mathrm{LU}$ & \\
& Kayu Bulan & $122.993811^{\circ} \mathrm{BT}$ & Pemukiman \\
7 & Kelurahan & $0.563475^{\circ} \mathrm{LU}$ & Muara Sungai \\
& Hunggaluwa & $122.982868^{\circ} \mathrm{BT}$ & Biyonga \\
& Kelurahan & $0.573587^{\circ} \mathrm{LU}$ & Area Eceng \\
& Hunggaluwa & $122.969022^{\circ} \mathrm{BT}$ & Gondok \\
\hline
\end{tabular}

\section{Prosedur Peneltian}

\section{Pengambilan sampel}

Parameter kualitas air yang diukur secara insitu terdiri dari suhu, $\mathrm{pH}$, kecerahan, konduktivitas, dan Oksigen terlarut (DO). Pengambilan sampel air untuk pengukuran kualitas air di laboratorium dilakukan menggunakan point sampler pada kedalaman $5 \mathrm{~m}$ dari permukaan air. Sampel air yang telah masuk pada point sampler dipindahkan pada botol sampel yang telah diberi label sesuai stasiun sampling.Botol sampel yang telah berisi sampel air dibungkus dengan 
aluminium foil dan disimpan pada coolbox agar sampel air terlindung dari kontaminasi bakteri dan kondisi kualitas air sampel tidak berubah sampel.

\section{Analisis Data}

Untuk mengetahui tingkat pencemaran perairan yang terjadi dilakukan perhitungan dengan perhitungan indeks pencemaran Kirchoff 1991, yaitu

Keterangan :

$$
C I=\prod_{i=1}^{n} q i^{w i}
$$

$\mathrm{CI}=$ nilai Indeks Pencemaran

$\mathrm{q}=$ nilai dari kurva baku sub indek parameter dengan skala pembobotan 0 - 100

$\mathrm{w}=$ nilai konstanta bobot kepentingan dari setiap parameter, nilainya dari 0 sampai 1

Nilai w dari parameter yang diukur dapat dilihat pada Tabel 2.

Tabel 2. Nilai w masing-masing parameter

\begin{tabular}{llcc}
\hline No & Paramater & Satuan & Nilai Faktor w \\
\hline & Oksigen & $\%$ & 0.2 \\
1 & terlarut & $\mathrm{mg} / 1$ & 0.2 \\
2 & BOD & & 0.1 \\
3 & $\mathrm{pH}$ & $\mu \mathrm{mhos} / \mathrm{cm}$ & 0.07 \\
4 & DHL & ${ }^{\circ} \mathrm{C}$ & 0.08 \\
5 & Suhu & $\mathrm{mg} / 1$ & 0.15 \\
6 & Amoniak & $\mathrm{mg} / 1$ & 0.1 \\
7 & Nitrat & $\mathrm{mg} / 1$ & 0.1 \\
8 & Orthophspat & Jumlah & $\mathbf{1}$ \\
\hline
\end{tabular}

Nilai CI yang diperoleh digunakan untuk menetapkan tingkat pencemaran dalam kriteria : belum tercemar (84-100), tercemar ringan (57-83), tercemar sedang (2856) dan tercemar berat (0-27).

Penentuan status pencemaran logam ditentukan dengan menggunakan indeks pencemaran berdasarkan Keputusan Menteri Negara Lingkungan Hidup Nomor 115 Tahun 2003 tentang Pedoman Penentuan Status Mutu Air

$$
\mathrm{PIj}=\sqrt{ }(\mathrm{Ci} / \mathrm{Lij}) 2 \mathrm{M}+(\mathrm{Ci} / \mathrm{Lij}) 2 \mathrm{R}
$$

Dimana Lij adalah konsentrasi parameter kualitas air dalam baku mutu peruntukan air (j), Ci adalah konsentrasi parameter kualitas air hasil survei, PIj adalah indeks pencemaran bagi peruntukan (j), (Ci/Lij)M merupakan nilai Ci/Lij Maksimum dan $(\mathrm{Ci} / \mathrm{Lij}) \mathrm{R}$ adalah nilai $\mathrm{Ci} / \mathrm{Lij}$ rata-rata.

Berikut ditetapkan kriteria tingkat pencemaran logam :

$1.0 \leq \mathrm{PIj} \leq 1,0$ : Memenuhi baku mutu (kondisi baik)

$2.1,0<\mathrm{PIj} \leq 5,0$ : Tercemar ringan 
$3.5,0<\mathrm{PIj} \leq 10$ : Tercemar sedang

4.PIj>10: Tercemar berat

\section{HASIL DAN PEMBAHASAN}

\section{Tingkat Pencemaran Perairan Danau Limboto Menurut Indeks Kimia Kirchoff}

Berdasarkan hasil penelitian diperoleh data pengukuran kualitas pada perairan Danau Limboto yang ditampilkan pada Tabel 3.

Tabel 3. Data Pengukuran Kualitas Air

\begin{tabular}{cccccccccc}
\hline $\begin{array}{c}\text { Paramete } \\
\text { r }\end{array}$ & \multirow{2}{*}{ Satuan } & \multicolumn{10}{c}{ Stasiun } \\
\cline { 3 - 10 } Suhu & ${ }^{\circ} \mathrm{C}$ & 31 & 34 & 30 & 30 & 31 & 32 & 33 & 32 \\
$\mathrm{pH}$ & - & 8.1 & 8.5 & 8.4 & 8.3 & 8.5 & 8 & 8 & 8.1 \\
$\mathrm{DO}$ & $\mathrm{mg} / 1$ & 14.4 & 19.8 & 14.6 & 9.8 & 18.7 & 10.3 & 11.8 & 12.3 \\
$\mathrm{BOD} 5$ & $\mathrm{mg} / 1$ & 13 & 13 & 7 & 7 & 7 & 26 & 40 & 50 \\
Nitrat & $\mathrm{mg} / 1$ & 3.52 & 4.87 & 3.51 & 3.33 & 3.76 & 4.59 & 4.6 & 4.45 \\
& & 0.06 & 0.028 & 0.02 & 0.001 & 0.02 & 0.03 & 0.05 & 0.01 \\
Amoniak & $\mathrm{mg} / 1$ & 0 & 2 & 4 & 1 & 1 & 1 & 7 & 7 \\
& & 0.00 & & 0.01 & & 0.00 & 0.01 & 0.01 & 0.01 \\
Phospat & $\mathrm{mg} / 1$ & 6 & 0.051 & 3 & 0.015 & 9 & 8 & 4 & 2 \\
& $\mu \mathrm{mhos} / \mathrm{c}$ & & & & & & & & $\mathbf{7}$ \\
DHL & $\mathrm{m}$ & 267 & 254 & 257 & 279 & 271 & 240 & 212 & 256 \\
\hline
\end{tabular}

Tabel 3 menunjukkan suhu perairan Danau Limboto berkisar $30-34{ }^{\circ} \mathrm{C}$. Secara umum nilai suhu pada perairan Danau Limboto sebagian besartelah berada di atas standar baku mutu PPRI No 82 Tahun 2001 kelas II untuk perikanan budidaya air tawar yaitu 20-30 ${ }^{\circ} \mathrm{C}$. Effendi (2003), menyatakan bahwa suhu suatu badan air dipengaruhi oleh musim lintang (latitude), ketinggian dari permukaan laut (altitude), waktu dalam satu hari, sirkulasi udara, penutupan awan, dan aliran serta kedalaman dari badan air. Perubahan suhu berpengaruh terhadap proses fisika, kimia, dan biologi dan air. Suhu air terutama di lapisan permukaan ditentukan oleh pemanasan matahari yang intesitasnya berubah terhadap waktu, oleh karena itu suhu air akan seirama dengan perubahan intensitas penyinaran matahari.

Nilai $\mathrm{pH}$ air yang terukur padaperairan Danau Limboto berkisar 8-8.5. Umumnya nilai $\mathrm{pH}$ pada semua stasiun stasiun pengambilan sampel masih tergolong normal sesuai nilai baku mutu PPRI No. 82 tahun 2001 kelas II untuk perikanan budidaya air tawar yaitu berkisar antara 6-9. Nilai $\mathrm{pH}$ sangat penting sebagai parameter kualitas air karena ikan dan biota air lainnya hidup pada 
kisaran $\mathrm{pH}$ tertentu. Ikan nila hidup pada nilai pH berkisar antara 6-8,5 (Cahyono, 2000).

Oksigen terlarut/dissolved oxigen (DO) adalah jumlah oksigen yang terlarut dalam air yang berasal dari fotosintesa dan absorbsi atmosfer/udara. Nilai DO menunjukkan nilai yang tinggi dan berada di atasstandar baku mutu yang ditetapkan oleh PPRI No.82 tahun 2001 untuk kelas II. Nilai oksigen terlarut dari semua stasiun pengambilan sampel berkisar 9.8- $19.8 \mathrm{mg} / 1$. Menurut Efendi (2003) kadar oksigen terlarut yang tinggi tidak menimbulkan pengaruh fisiologis bagi manusia. Ikan dan organisme akuatik lain membutuhkan oksigen terlarut dengan jumlah cukup. Kebutuhan oksigen sangat dipengaruhi oleh suhu dan bervariasi antar organisme. Di perairan danau, oksigen lebih banyak dihasilkan oleh fotosintesis alga yang banyak terdapat pada mintakat epilimnion. Pada perairan tergenang yang dangkal dan banyak ditumbuhi tanaman pada zona litoral, keberadaan oksigen lebih banyak dihasilkan oleh aktivitas fotosintesis tumbuhan air.

Nilai $\mathrm{BOD}_{5}$ perairan Danau Limboto berkisar 7-50 mg/1. Nilai tersebut berada di atas standar baku mutu yang ditetapkan oleh PPRI No.82 tahun 2001 untuk kelas II sebesar $3 \mathrm{mg} / 1$. Konsentrasi BOD 5 yang tinggi menunjukkan banyaknya kadar bahan organik yang harus dioksidasi sehingga membutuhkan oksigen yang lebih dan juga menunjukkan bahwa perairan tersebut sudah tercemar oleh bahan organik (Effendi 2003).

Konsentrasi nitrat dan amoniak perairan Danau Limboto berkisar 3.51-4.59 $\mathrm{mg} / 1$ dan 0.01-0.06 mg/1. Hal ini menunjukkan konsentrasi nitrat dan amoniak secara umum masih berada di bawah standar baku mutu yang ditetapkan oleh PPRI No.82 tahun 2001 untuk kelas II sebesar $10 \mathrm{mg} / 1 \mathrm{dan} 0.02 \mathrm{mg} / 1$. Menurut Effendi (2003) kadar amoniak yang baik bagi kehidupan ikan air tawar kurang dari $1 \mathrm{mg} / \mathrm{L}$. Apabila kadar amoniak telah melebihi $1,5 \mathrm{mg} / \mathrm{L}$, maka perairan tersebut telah terjadi pencemaran.

Konsentrasi phospat pada perairan Danau Limboto berkisar 0.006-0.051 mg/1. sedangkan nilai konduktivitas berkisar 212-279 $\mu \mathrm{mhos} / \mathrm{cm}$. Hal ini menunjukkan bahwa konsentrasi phospat dan konduktivitas masih berada di bawah standar baku mutu yang telah ditetapkan sehingga masih pada kisaran normal untuk melakukan kegiatan budidaya. Nilai Kualitas air di perairan Danau Limboto sangat penting untuk diketahui, dimana Danau Limboto merupakan salah 
satu perairan yang berpotensi mengalami perubahan lingkungan akibat adanya pembuangan limbah pertanian, limbah industri dan limbah rumah tangga. Kualitas air berperan penting bagi kemampuan organisme untuk mempertahankan kehidupannya Wahyuniet. al (2013).

Bedasarkan hasil perhitungan indeks kimia Kirchoff maka diperoleh tingkat pencemaran perairan Danau Limboto yang dapat dilihat pada Tabel 3.

Tabel 3.Tingkat Pencemaran perairan Danau Limboto berdasarkan Indeks Kimia Kirchoff

\begin{tabular}{ccc}
\hline Stasiun & $\begin{array}{c}\text { Nilai Indeks } \\
\text { Kimia } \\
\text { Kirchoff }\end{array}$ & Kriteria \\
\hline 1 & 60.51 & Tercemar Ringan \\
2 & 59.13 & Tercemar Ringan \\
3 & 68.62 & Tercemar Ringan \\
4 & 68.13 & Tercemar Ringan \\
5 & 70.64 & Tercemar Ringan \\
6 & 55.82 & Tecemar Sedang \\
7 & 42.58 & Tecemar Sedang \\
8 & 43.01 & Tecemar Sedang \\
\hline
\end{tabular}

Hasil perhitungan indeks kimia Kirchoff menunjukkan tingkat pencemaran perairan Danau Limboto pada stasiun 1, 2, 3, 4 dan 5 tergolong perairan yang tercemar ringan dengan nilai indeks kimia kirchoff berkisar 59.13-70.64, sedangkan stasiun 6,7 dan 8 tergolong perairan yang tercemar sedang dengan nilai indeks kirchoff berkisar 42.58-55.82. Hal ini diduga karena pada peraran Danau Limboto banyak terdapat karamba untuk budidaya perikanan, sehingga sisa pakan ikan yang tidak termakan akan meningkatkan beban organik dan nutrien ( $\mathrm{N}$ dan P) yang terlarut dalam perairan. Selain itu juga disebabkan oleh pembuangan limbah domestik dan limbah pertanian dari aktivitas masyarakat di sekitar Danau Limboto.Menurut penelitian Suryono et al., (2010) tingkat pencemaran badan air Danau Limboto tergolong tercemar ringan sedangkan pada daerah inlet Danau Limboto tergolong tercemar berat. Mustafa, et al., (2008) yang menyatakan bahwa faktor yang menyebabkan tingginya indeks pencemaran suatu perairan pada umumnya disebabkan oleh limbah domestik (domestic urban wastes), limbah cair perkotaan (urban stormwater), limbah cair pemukiman (sewage), kegiatan pertambangan, limbah industri (industrial wastes), limbah pertanian (agricultural 
wastes), limbah perikanan budidaya dan air limbah pelayaran (shipping waste water).

\section{Tingkat Pencemaran Logam Perairan Danau Limboto}

Pencemaran suatu perairan oleh unsur - unsur logam berat dapat mengganggu ekosistem juga secara tidak langsung juga dapat merusak biota perairan dan kesehatan manusia (Budiastuti et. al., 2016). Kadmium (Cd) dan timbal $(\mathrm{Pb})$ termasuk logam berat yang beracun terhadap makhluk hidup (Darmono, 2006). Logam berat tersebut dapat mengumpul (terakumulasi) di dalam tubuh suatu biota dan tetap tinggal dalam tubuh dalam jangka waktu yang lama sebagai racun. Keracunan timbal dan kadmium ini menyebabkan kadarnya tinggi dalam aorta, hati, ginjal, pankreas, paru-paru, tulang, limpa, testis, jantung dan otak (Supriyanto et al., 2007). Hasil perhitungan Indeks pencemaran logam timbal dan kadmium perairan Danau Limboto ditampilkan pada Tabel 4.

Tabel 4. Tingkat Pencemaran Logam perairan Danau Limboto

\begin{tabular}{cccc}
\hline \multirow{2}{*}{ Stasiun } & \multicolumn{2}{c}{ Nilai Indeks Pencemaran Logam } & \multirow{2}{*}{ Kriteria } \\
\cline { 2 - 3 } & $\mathbf{P b}$ & $\mathbf{C d}$ & \\
\hline 1 & 0.3 & 0.5 & Kondisi Baik \\
2 & 0.3 & 0.4 & Kondisi Baik \\
3 & 0.4 & 0.5 & Kondisi Baik \\
4 & 0.3 & 0.4 & Kondisi Baik \\
5 & 0.4 & 0.6 & Kondisi Baik \\
6 & 0.4 & 0.8 & Kondisi Baik \\
7 & 0.1 & 0.5 & Kondisi Baik \\
8 & 0.1 & 0.8 & Kondisi Baik \\
\hline
\end{tabular}

Berdasarkan hasil perhitungan indeks pencemaran logam menurut KepMen LH No.115 tahun 2003 didapatkan nilai Indeks Pencemaran logam Pb dan Cd pad Perairan Danau Limboto. Hasil penelitian menunjukkan tingkat pencemaran logam $\mathrm{Pb}$ dan $\mathrm{Cd}$ masih berada dalam kondisi baik, dimana nilainya masih memenuhi standar maku mutu yang telah ditetapkan yaitu nilai $0 \leq \operatorname{PIj} \leq 1,0$.

Logam berat secara umum masuk ke lingkungan dengan dua cara, yakni secara natural dan antropogenik (terlepas ke lingkungan dengan campur tangan manusia atau tidak alami) (Ali et al., 2013). Menurut Agustina et. al., (2012) keberadaan logam berat $\mathrm{Pb}$ sendiri dalam badan perairan biasanya berasal dari aktivitas yang dilakukan oleh manusia yang menghasilkan limbah, sampah sampah metabolik dan korosi pipa-pipa air. Selain itu limbah-limbah industri, 
kegiatan pelayaran dan pelabuhan serta kegiatan pertanian, perkebunan dan perikanan juga merupakan sumber dari logam berat $\mathrm{Pb}$.

\section{KESIMPULAN}

Tingkat pencemaran Perairan Danau Limboto pada stasiun 1, 2, 3, 4 dan 5 tergolong tercemar ringan dengan nilai indeks kimia kirchoff berkisar 59.13-70.64, sedangkan stasiun 6, 7 dan 8 tergolong tercemar sedang dengan nilai indeks kimia kirchoff berkisar 42.58-55.82. Tingkat pencemaran logam $\mathrm{Pb}$ dan $\mathrm{Cd}$ pada perairan Danau Limboto masih berada dalam kondisi normal dengan nilai indeks pencemaran logam $0 \leq \mathrm{PIj} \leq 1$ yaitu memenuhi baku mutu (kondisi baik).

\section{UCAPAN TERIMA KASIH}

Ucapan Terima Kasih Kepada Kemenristekdikti dan Universitas Gorontalo sehingga kegiatan penelitian ini dapat terlaksana dengan baik.

\section{DAFTAR PUSTAKA}

1. Ali, H., Khan, E., Sajad, M.A., 2013. Phytoremediation of Heavy Metal Concepts and Applications. Chemosphere 91 (2013) 869-881.

2. Agustina, Y., Amin, B., dan Thamrin . 2012. Analisis Beban dan Indeks Pencemar di Tinjau dari Parameter Logam Berat di Sungai Siak Kota Pekan Baru. Jurnal Ilmu Lingkungan Volume 6 Nomor 2.

3. Budiastuti, P., Mursid, M., dan Nikie a. Y. D. 2016. Analisis Pencemaran Timbal pada Bada Air Sungai Babon Kecamatan Genuk Semarang. Jurnal Kesehatan Masyarakat Volume 4 Nomor 5 Oktober 2016.

4. Cahyono, B. 2000. Budidaya Ikan Air Tawar. Penerbit Kanisius. Yogyakarta.

5. Darmono. 2006. Lingkungan Hidup dan Pencemaran, Hubungannya dengan Toksikologi Senyawa Logam. UI Press. Jakarta.

6. Effendi, H. 2003. Telaah Kualitas Air. Kanisius, Yogyakarta. 254 hlm

7. Kristanto, Philip. 2002. Ekologi Industri. Andi offset. Yogyakarta

8. Keputusan Menteri Kependudukan dan Lingkungan Hidup No. 115 Tahun 2003. Tentang Pedoman Penentuan Stastus Mutu Air. Lampiran 2, Tanggal 10 Juli 2003 Tentang Penentuan Status Mutu Air Dengan Metode Indeks Pencemaran. Sekretariat Menteri Negara Kependudukan dan Lingkungan Hidup. Jakarta 
9. Mustafa, G., Kashmiri, M.A., Shahzad, A., Mumtaz, M.W dan Arshad, M. 2008. Estimation of Pollution Load at Critical Points in Stream Water Using Various Analytical Methods. Journal Applied Environmental Sciences. Vol 3 : 97-105.

10.Pemerintah Provinsi Gorontalo. 2016. Laporan Akhir Kajian Lingkungan Hidup Strategis untuk RTR-KSP Kawasan Danau Limboto Tahun 2016-2036.

11.Peraturan Presiden Republik Indonesia. 2001. Pengelolaan Kualitas Air dan Pengendalian Pencemaran.

12. Supriyanto c, Samin, Zainul kamal.2007. Analisis cemaran logam berat $p b$, cu, dan cd pada ikan Air tawar dengan metode spektrometri nyala Serapan atom (ssa). Seminar nasional iii Sdm teknologi nuklir, Yogyakarta.

13. Suryono, T., Senny, S., Endang, M., dan Rosidah. 2010. Tingkat Kesuburan dan Pencemaran danau Limboto Gorontalo. Jurnal Oseanologi dan Limnologi Indonesia 36(1): 49-61.

14.Wahyuni Hasti, Setia Budi, Dwi P. 2013. Kandungan Logam Berat pada Air, Sedimen dan Plankton di Daerah PenambanganMasyarakat Desa Batu Belubang Kabupaten Bangka Tengah.Prosiding Seminar. 